\title{
The Integration of Vegetation in Architecture, Vertical and Horizontal Greened Surfaces
}

\author{
Katia Perini (Corresponding author) \\ Faculty of Architecture, University of Genoa \\ Stradone S. Agostino, Genoa37 - 16123, Italy \\ Tel: 39-010-209-5758 E-mail: katia.perini7@gmail.com
}

Adriano Magliocco

Faculty of Architecture, University of Genoa

Stradone S. Agostino, Genoa37 - 16123, Italy

Tel: 39-010-209-5766 E-mail: magliocc@arch.unige.it

Received: December 12, 2011

Accepted: January 16, 2012 Published: April 1, 2012

doi:10.5539/ijb.v4n2p79

URL: http://dx.doi.org/10.5539/ijb.v4n2p79

\begin{abstract}
Greening the building envelope is a rapidly developing field in the words of ecology, horticulture and built environment, since it's an opportunity for combining nature and buildings (linking different functionalities) in order to address environmental issues in dense urban surroundings. A green envelope is a good opportunity for improving the urban environment conditions, since European cities tend to be densely built, becoming the scene of important environmental issues relative to pollution in the atmosphere. Vegetation allows improving the air quality, incrementing biodiversity and reducing urban heat islands thanks to its cooling and refreshing capacity, beside an aesthetical value. The massive integration of vegetation in architecture allows exploiting the surface (both horizontal and vertical) of the buildings to obtain the benefits mentioned above and, consequently, an improvement in environmental quality and inhabitants' wellbeing.

This paper discusses the environmental benefits achievable with the integration of vegetation in built space, the main characteristics of green envelope elements and typologies connected to theirs functional and formal peculiarity, to the contribution on the building envelope performances and to environmental and economical aspects.
\end{abstract}

Keywords: Vertical greening systems, Green roofs, Ground treatment, Sustainability, Urban environment

\section{Introduction}

Greening the building envelope is a rapidly developing field in the words of ecology, horticulture and built environment (Dunnett \& Kingsbury, 2008), since it's an opportunity for combining nature and buildings (linking different functionalities) in order to address environmental issues in dense urban surroundings (Bohemen, 2005).

Green façades and green roofs offer the potential to learn from traditional architecture. The earliest form of vertical gardens dates from 2000 years ago in the Mediterranean region (Köhler, 2008) and ornamental roof gardens have been developed initially by the civilization of the Tigri and Euphrates River valleys (the most famous examples of which were the Hanging Gardens of Babylon in the seventh and eight centuries B. C.; Dunnett \& Kingsbury, 2008). Several examples of green roofs and façades back to 18th-19th century can be found in north Europe regions (figure 1), such as sod roofs in Norway, or climbing plants for shading vertical surfaces in Mediterranean regions. Nowadays this kind of building envelope also incorporates advanced materials and other technologies to promote sustainable building functions (Köhler, 2008).

The benefits gained thanks to the use of vegetation are the subject of studies and researches starting from the eighties (Köhler, 2008). The first projects which revolved around nature and environment, such as the works of the SITE group, Emilio Ambasz, Hundertwasser and Oswald Mathias Ungers, were published in this period (Lambertini, 2007). 
The ecological theories, from 1866 up until today, have contributed to the diffusion of a better awareness as far as our actions on a global level are concerned. The attention towards themes regarding ecology and sustainability in the last fifty years has developed with different intensities in parallel to a series of political and historical events, such as the first big energy crisis or the establishment that the hole in the ozone layer exists (1985). The iconography of sustainability today strongly conditions its collective image. In architecture the cases of formal choices based on the need to communicate and make explicit the sustainability of a project, even regardless of real eco-compatible aspects, is ever more frequent (Cassinelli \& Perini, 2010).

An analysis based on relevant architectural periodicals (Domus \& The Architectural Review; Perini, 2012) dating from 2000 to 2010, describing the current approach used in green architecture design and its relative aesthetic outcome, has brought to the light the wide development and diffusion of the integration of vegetation in architecture. The recurrent design approaches can be classified into: green envelope for environmental and microclimatic control, natural maquillage and relation between architecture and landscape. The approaches used have an influence, beside the aesthetic outcome, on functional characteristics. Considering the firs design approach defined the project is mainly conceived in order to exploit the vegetation and system characteristics for a sustainable built space; speaking about natural maquillage refers to cases where the integration of vegetation (mainly vertical greening systems) is used for communicating sustainably aspects, such as advertisement spot (figure 2); the last approach defined, relation between architecture and landscape, regards the use of vegetation for covering architecture in the context thanks to a natural camouflage. A famous example of this is the work of Emilio Ambasz according to his slogan "The green over the grey" (Ambasz, 2009).

Beside the aesthetical value, a green envelope is a good opportunity for improving the urban environment conditions, since European cities tend to be densely built, becoming the scene of important environmental issues relative to pollution in the atmosphere. This has consequences on the physical wellbeing and comfort of the local inhabitants. The bad air quality of some cities (many Italian cities) is more a sanitary emergency than an environmental problem. Only the PM10 level causes every year more than 350.000 premature deaths in Europe, considering what the Europe Commission declared.

The high levels of pollution in the atmosphere along with the "cementification" of urban areas and the excess of asphalted surfaces compared to the greened ones are the cause of the urban heat island phenomenon. The higher temperatures $\left(2-5^{\circ} \mathrm{C}\right.$, Taha, 1997) inside cities in comparison to the suburban and rural areas are determined by this phenomenon. This has evident effects both on the environment and on the wellbeing of city dwellers.

The problematic situation of the pollution and of the inhabitants discomfort is related to the inadequate quantity of vegetation and green areas in the urban environment, which has also been demonstrated through research as fundamental for man's psychological wellbeing. A socio-clinical study by Perussa (1990) proves that the presence of vegetation has a central and decisive role on the wellbeing and residential satisfaction of the city's inhabitants, and consequently has a crucial role in determining the real estate value of the urban area.

Vegetation allows improving the air quality, incrementing biodiversity and reducing urban heat islands thanks to its cooling and refreshing capacity (Ottelé et al., 2010; Onishi, 2010; Köhler, 1993). It also allows reducing air conditioning implant emissions, even in areas characterized by Mediterranean climate (Dunnett \& Kingsbury, 2008).

Considering the difficulty in finding empty spaces for the plantation of vegetation in the urban fabric, the buildings themselves can provide the necessary space. The massive integration of vegetation in architecture allows exploiting the building surfaces (both horizontal and vertical) to obtain the benefits mentioned above and, consequently, an improvement in environmental quality and the inhabitants' wellbeing.

Beside the environmental benefits achievable with the integration of vegetation in built space, this paper discusses the main characteristics of green envelope elements and typology connected to theirs functional and formal peculiarities, to the contribution on the building envelope performances and to environmental and economical aspects.

\section{Definitions and Functional Characteristics}

For every type of integration, which can be schematically listed as application of vegetation to the horizontal skin (green roofs), application of vegetation to the vertical skin (vertical greening systems) and ground treatment in the vicinity of the building, the project must closely consider the climatic and environmental characteristics of the intervention site considering the type of support and plant specimen chosen to avoid damages and design mistakes (Perini et al., 2011).

The practice of green roofs has been mainly developed in cold regions (northern Europe) where the climatic 
conditions are favourable to the growth of vegetation (Fioretti et al. 2010). Many systems are now available on the market and are commonly classified in intensive, semi-intensive and extensive solutions considering the thickness of the substrate and thus of the stratigraphy. The green roofs layers typically consist in: a waterproofing membrane to protect the roof, a root membrane, a drainage layer design to carry excess runoff and to store the water (realized with either some coarse grained porous media or plastic profiled elements), a filter fabric, and finally the growing medium (often a lightweight synthetic soil that is porous and inherently inert, with nutrients added for plant growth) and the plant species (Fioretti et al. 2010). Green roofs can be used for many construction types with lower inclination than $10^{\circ}$ with intensive solutions or lower than $30^{\circ}$ with semi-intensive and extensive ones and with higher inclination than $30^{\circ}$ with special technical solutions (called inclined semi-intensive or inclined extensive).

The intensive green roofs are usually constituted by a substrate thickness higher than $30 \mathrm{~cm}$, are accessible, as gardens, have a high visibility and require irrigation systems and a medium-high maintenance (figure 3 ). These systems can support the whole range of vegetation types (from trees and shrubs through to herbaceous planting and lawns) and can guarantee insulation and thermal mass to the building, beside a surface temperature reduction, as for all the types of green envelope (Dunnett \& Kingsbury, 2008).

The substrate thickness for semi-intensive green roofs is usually $15-30 \mathrm{~cm}$. This is a middle way solution, it requires a medium (periodical) maintenance with an irrigation system, it's accessible and characterized by a medium visibility and it can still guarantee a good insulation to the roof and lower surface temperatures. The plant types that can be used are small shrubs or herbaceous planting and lawns (figure 4, Dunnett and Kingsbury, 2008).

Finally the extensive green roofs (substrate thickness $5-15 \mathrm{~cm}$ ) can be defined as ecological protection layers (figure 5) and are often used in combination with photovoltaics, because the output of cells is higher at lower temperature obtained thanks to a green layer (Dunnett \& Kingsbury, 2008). The maintenance needs are very low also because these systems cannot be walked on. The visibility is pretty low due to the plant types used (sedum or lawn). Extensive green roofs are the most widely used green roofs due to their low costs, lightweight, shallow soil layer and independence from delicate maintenance (Carter \& Keeler, 2008).

Beside the characteristics described, technology and materials employed, the local climate and the precipitation regime, the orientation and maintenance of the rooftop are among the most influencing parameters that may affect the expected performance of a green roof (Fioretti et al., 2010).

Vertical green, also commonly referred to as a "vertical garden", is a descriptive term that is used to refer to all forms of vegetated wall surfaces (www.greenroofs.org). Vertical greening systems can be classified into green façades and living wall systems according to their growing method (Dunnett and Kingsbury, 2008; Köhler, 2008).

Green façades are based on the use of climbers attached directly to the building surface (figure 6), as in traditional architecture, or supported by cables or trellis (indirect green façade). In the first case climbers planted on the base of the building allow to obtain a cheap façade greening but with possible implications for building works that need to be carried out. Besides that, some climbing plants can grow 5 or 6 meters high, others around 10 meters and some species at least 25 meters (Dunnett \& Kingsbury, 2004). In the case of an indirect greening system (vegetation is supported by cables or meshes), many materials can be used as support for climbing plants as, for example, steel (coated steel, stainless steel, galvanized steel), types of wood, plastic or aluminium. Each of the materials enumerated changes the aesthetical and functional properties due to the different weight, profile thickness, durability and cost (Ottelé et al., 2011). Also planter boxes can be used to reach superior heights or to support a wider range of vegetation as shrubs (figure 7).

Living wall systems are constructed from modular panels, each of which contains its own soil or other artificial growing mediums, as for example foam, felt, perlite and mineral wool, based on hydroponic culture, using balanced nutrient solutions to provide all or part of the plant's food and water requirements (Dunnett \& Kingsbury, 2008). The plant type for these systems is normally evergreen (as small shrubs) and is not naturally growing vertically. Many systems have been developed in the last few years, each one with different characteristics, starting from the growing medium, as for example the system shown in figure 8 , based on felt layers working as substrate and water proofing, supported by a PVC sheet with plants not completely grown, and the one shown in figure 9 based on HDPE planter boxes filled with soil.

The living wall systems increase the variety of plants that can be used beyond the use of climbing plants and offers much more creative (aesthetical) potential. The plant choice affects also functional aspects of a greened façade. An evergreen plant protects the façade from wind flow, snow and rain in winter seasons, a deciduous 
climber allows the building envelope to change visually and affects also its performances. Living wall systems guarantee a higher contribution to the building envelope performances, this is due to the continuous layers protecting from atmospheric agents and to the insulation properties of the materials involved (Perini et al., 2011).

Beside this, it is possible to assume that, from a functional point of view, most of the living walls systems (LWS), compared to green façades, demand a more complex design, which must consider a major number of variables (several layers are involved, supporting materials, control of water and nutrients, etc.), and are often very expensive, up to 1200 Euros $/ \mathrm{m}^{2}$ ), energy consuming and difficult to maintain (Ottelé et al., 2011; Perini et al. 2011). It also has to be taken into account the durability of the systems, for example a panel of a LWS based on felt layers has an average life expectancy of ten years, but the LWS based on planter boxes is more durable (more than fifty years, Ottelé et al., 2011).

The ground treatment in the vicinity of the building consists in the use and disposal of vegetation (trees or shrubs) next to the building envelope to obtain a reduction (wind barrier) or an increase (Venturi effect) of air flow, a shading effect on windows and hard surfaces, andair temperature reduction. These effects depend on the layout area around the building, for example by greening an interstitial area like a court it's possible to obtain lower air temperatures and thus interior ventilation (figure 10), and on the plant characteristics that affect the shading and evapotranspiration effects (Scudo \& Ochoa De La Torre, 2003). Also climbing plants can be used for greening the area in the vicinity of the building, working similarly to many big trees, as in the MFO park project (figure 11)

Considering the formal and functional characteristics the plant specie choice depends, beside the ecological needs, on the contribution required to the vegetation (building microclimate). To obtain an effective wind barrier during winter seasons the foliation period of trees and shrubs has to be evergreen and the plants should have a winter shadow coefficient lower than $0.25 \%$; differently when it's required cooling and shading effect the plants can be both evergreen and deciduous and need to have a low summer shadow coefficient $(<15 \%)$ and a daily transpiration higher than 8 gr. $\mathrm{H}_{2} \mathrm{Oxgr.leaf}$ (Scudo and Ochoa De La Torre, 2003).

All the integration modalities described can be used for new constructions and retrofitting projects. Considering especially retrofitting projects, the system choice has to consider the structural and architectural characteristics of the building, since some systems are more flexible than others, and the microclimatic benefits needed to improve the building efficiency (cooling, insulation; Perini et al. 2011). For example the ground treatment can be used only when there is enough space in the vicinity of the building, which doesn't happen very often in dense cities. Green roofs add extra weight to the building structure (till $500 \mathrm{~kg} / \mathrm{m}^{2}$ ); this aspect has to be considered for evaluating if, and with which system, a green roof can be used for retrofitting. Also vertical greening systems add extra weight to the building envelope and those systems are often difficult to maintain and expensive, as mentioned above.

\section{Benefits Related to Green Envelope}

The environmental benefits related to green building envelope operate at a range of scales (building scale and city or neighbourhood). The integration of vegetation in architecture improves also the visual, aesthetic and social aspects of the urban area, which have a high influence on the economical value of a building or neighbourhood, and contributes to enhancing human health. Urban vegetation is widely recognized as therapeutic and there are a number of research studies illustrating this (Ulrich, 1986; Dunnett \& Kingsbury, 2004).

The benefits related to the larger scale work only if a large surface in the same area is greened;thesemainly regard the improvement of air quality and urban wildlife (biodiversity) and the mitigation of urban heat island effect (Köhler, 2008). The air quality improvement due to vegetation is related to the absorption of fine dust particles and the uptake of gaseous pollutants such as $\mathrm{CO}_{2}, \mathrm{NO}_{2}$ and $\mathrm{SO}_{2}$. Carbon dioxide is used by plants for the photosynthesis process creating oxygen and biomass; nitrogen and sulphur dioxides are converted into nitrates and sulphates in the plant tissue. The fine dust particles (PM), especially the smaller size fractions $(<10$ $\mu \mathrm{m}$ ), are mainly adhered to the outside of the plant parts (Ottelé et al., 2010; Sternberg, 2010); therefore vegetation is a perfect anchor for airborne particles at different heights. Dust particles smaller than $2.5 \mu \mathrm{m}$ are relevant mainly in the dense urban area because they can be inhaled deeply into the respiratory system and cause health issues and damage to human beings (Powe \& Willis, 2004).

The urban heat island (UHI) phenomenon can cause air temperature in the cities to be $2-5^{\circ} \mathrm{C}$ higher than those in the surrounding rural areas. This is mainly caused by the amount of artificial surfaces (high albedo) compared with natural land cover (Taha, 1997; Onishi, 2010). A study conducted by Onishi et al. (2010) shows lower temperatures $\left(2-4^{\circ} \mathrm{C}\right)$ inside areas covered with trees. A green envelope can intercept the radiation and thus 
reduce the warming up of hard surfaces, great quantities of solar radiation are adsorbed for the growth of plants and their biological functions (Krusche et al, 1982).

The effect of evapotraspiration and shading on the humidity level and temperature influences also the building microclimate, indoor and outdoor. A research conducted by Alexandri and Jones (2008) shows a temperature decrease in an urban canyon with green walls and green roofs for Mediterranean climate of $4.5^{\circ} \mathrm{C}$. The vegetation cooling effect can indirectly reduce the gas emissions connected to air conditioning (Dunnett and Kingsbury, 2004).

Green roofs are passive cooling techniques that stop incoming solar radiation from reaching the building structure below. The insulation properties depend, as previously described, on the green roof type (extensive, intensive or semi-intensive, Kumar \& Kaushik, 2005).

Considering the storm water management, a green roof system is able to significantly reduce storm water runoff generation - especially in Mediterranean region - in terms of runoff volume reduction, peak attenuation and increase of concentration time (Fioretti et al., 2010; Palla et al., 2011). This is an important field to investigate, since the growth of urban areas brings significant changes in the physical properties of land surfaces, and these modifications affect the hydrologic cycle by increasing runoff rates and volumes and decreasing the hydrograph base-flow components. Given the incidence of unused rooftops in urban areas (up to $40-50 \%$ of the impervious surfaces), green roofs are important determinants for the hydrologic restoration and an interesting alternative to more conventional building practices (Palla et al., 2009).

The benefits connected to the construction of a green wall at the building scale are mainly related to the cooling potential and the insulation properties. The cooling potential of green façades or vertical green is discussed in many studies. A study conducted in Germany by Bartfelder and Köhler (1987) shows a temperature reduction at the green façade in a range of $2-6^{\circ} \mathrm{C}$ compared to the bare wall. A recent study (Eumorfopoulo \& Kontoleon, 2009) shows a cooling potential for the Mediterranean climate till $10.8^{\circ} \mathrm{C}$ on the façade. Another recent study by Wong et al. (2009) in Singapore with vertical greening types shows a maximum reduction of $11.6{ }^{\circ} \mathrm{C}$. A study conducted by Perini et al. (2011) shows the potential of vertical green layers on reducing the wind velocity around building façades. Thanks to an extra stagnant air layer, which can be created inside the foliage, the benefit on the thermal resistance of the construction can be quantified by an increase of $0.09 \mathrm{~m}^{2} \cdot \mathrm{K} \cdot \mathrm{W}-1$. In the case of living wall systems the insulation properties of the material used can be taken into account.

Green façades and living wall systems (LWS) have different characteristics that can have influence on the cooling potential above described and the insulating properties. This happens due to the thickness of the foliage, water content, material properties and possible air cavities between the different layers.

Even a simple disposition of trees and shrubs can affect the building microclimate and improve the indoor and outdoor comfort. Plants can form an effective wind barrier, if disposed before the building to protect in the direction of the cold winter wind, mainly coming from the north. The shading and cooling effect can be relevant in the case of well grown plants with low summer coefficient and high daily transpiration levels. Considering $100 \%$ of sun light energy that falls on a leaf, $5-30 \%$ is reflected, $5-20 \%$ is used for photosynthesis, $10-50 \%$ is transformed into heat, $20-40 \%$ is used for evapotranspiration and $5-30 \%$ is passed through the leaf (Krusche et al. 1982).

\section{Environmental and Economic Aspects}

The requirements considered for the evaluation of natural materials and technologies have to relay not only on the analysis of the performances for accomplishing functional and architectonical characteristics. The requirements concern also the answer to global needs of all community, with respect to the sustainable use of resources, the control of the productive thread and the valorisation of ecosystem services.

Terrestrial ecosystems provide a number of vital services for people and society, such as biodiversity, food, fibre, water resources, carbon sequestration, and recreation. The future capability of ecosystems to provide these services is determined by changes in socio-economic characteristics, land use, biodiversity, atmospheric composition and climate (Metzger et al., 2006). Many aspects of our planet are changing rapidly due to human activities and these changes are expected to accelerate during the next decades for example rising atmospheric carbon dioxide results in global warming (IPCC, 2001a, b, c).

Greening the building envelope can be an opportunity to reduce the climate change, beside the environmental benefits above described. A wide replication of vegetation in the urban area can lead to significant results with respect to a temperature reduction. Furthermore the energy savings for heating and air conditioning will also lead a reduction of greenhouse gases emission, beside the plants biomass production. It is mandatory to minimize the 
environmental impact evaluating the sustainability of every system and also the economical impact to enable a wide use of those. Life cycle analysis and life cycle cost analysis can be effective tool for evaluating the sustainability (environmentally and economically) of a building element, with respect to the integral balance between the environmental load and the possible benefits, considering fabrication, transportation, installation, operation, maintenance, and disposal (Kosareo \& Ries, 2007).

Green roof technology has been developed in the last 20-30 years and several systems with different characteristics (economic and environmental impact) are available on the market (Dunnett \& Kingsbury, 2004). Many studies show that green roofs can offer benefits in winter heating reduction as well as summer cooling. For example, the work of Niachou et al. (2001) found an energy saving (cooling and heating) potential of green roofs of $3-7 \%$ for moderately insulated roof and of $31-44 \%$ for a non-insulated one thanks to a green roof. They identified that if energy costs increase or green roof construction costs decrease, then green roofs will become more economically attractive. Kosareo and Ries (2006) performed a comparative environmental life cycle assessment of a green roof for a $1115 \mathrm{~m}^{2}$ retail store. The conclusion was that although initial costs were high, the energy and cost savings made over the building lifetime made the green roof an environmentally preferable choice. Wong et al. (2003) found that while a life cycle costs of an extensive green were lower than the of an equivalent non-greened roof, for intensive roof or for roofs gardens the life cycle cost may not be less than the non-greened roof.

This is due to the initial and maintenance costs. The initial cost (given by Italian Companies) of an extensive green roof (figure 5) is $40-70 € / \mathrm{m}^{2}$; intensive or semi-intensive solutions can cost till $150 € / \mathrm{m}^{2}$, the range goes from 40 to $150 € / \mathrm{m}^{2}$ for the intensive green roof (figure 3) and from 70 to $150 € / \mathrm{m}^{2}$ for semi-intensive ones (figure 4). The highest prices regard the inclined semi-intensive solution (up to $170 € / \mathrm{m}^{2}$ ). It's important to specify that beside the contribution to the building envelope performances (considered for LCA and LCCA) it has to be taken into account the accessibility (garden green roof) and the visibility connected to the range of vegetation types that every system can support. These aspects could have an influence also on the real estate building value increase and thus could be also taken into account in a life cycle cost analysis.

Some of the vertical greening systems (LWS) are new and innovative technology. Besides the environmental benefits above described, it is eventually not clear if these systems (all or some) are sustainable due to the materials used, maintenance, nutrients and water needed. A study conducted by Ottelé et al. (2011), regarding a life cycle analysis of four greening systems, shows the environmental burden profile in relation to the energy savings for air conditioning and heating achievable. The results of the LCA show a higher environmental impact for living wall systems compared to green façades but also the potential of energy saving, especially for Mediterranean climate, and the possibility to combine functionalities also with a higher integration within the building envelope. The materials involved, due to their own environmental impact and durability aspects (for the supporting system and for the plant type) play an important role on the environmental burden profile (Ottelé et al., 2011).

The study concludes that direct greening systems (figure 6) have a very small influence on the total environmental burden, for this reason this type of greening, without any additional material involved, can be always considered a sustainable choice for both the climate situations examined (Mediterranean and temperate). Beside this the cost of a climbing plant is around 30-45€ $€ \mathrm{~m}^{2}$ (Perini et al., 2011). For the indirect greening systems with (figure 7) or without planter boxes the materials used have a high influence on the total environmental burden. For example wood, HDPE and steel can have an influence on the environmental burden of the system roughly 10 times lower than a stainless steel mesh (Ottelé et al., 2011). Also the economical aspects are very different according to the material used. In the case of a combined indirect greening system with planter boxes the cost range goes from $100-150 € / \mathrm{m}^{2}$ for HDPE to $400-500 € / \mathrm{m}^{2}$ for coated steel and up to $600-800 € / \mathrm{m}^{2}$ for stainless steel. Differently for indirect greening system with only a mesh as support for climbing plants the prices are for the three materials around $40-70 € / \mathrm{m}^{2}$ (Perini et al. 2011).

For the living wall systems the economical and environmental costs are usually higher. For example the living wall system based on felt layers (figure 8) has a high environmental burden due to durability aspects and the materials used (Ottelé et al., 2011) and the (initial) cost gets up to $750 € / \mathrm{m}^{2}$. The living wall system shown in figure 9 has a lower economical $\left(400-600 € / \mathrm{m}^{2}\right.$, Perini et al., 2011) and environmental impact. The study conducted by Ottelé et al. (2011) shows that this LWS doesn't have a major footprint due to the materials involved, since the materials affect positively the thermal resistance of the system. Beside this the living wall systems offer much more creative (aesthetical) potential and allow a higher integration within the building envelope that could reduce the environmental burden. 
For the ground treatment in the vicinity of the building the environmental impact can be very low (affected mainly by the transportation distances), since the total burden is given by vegetation as in the example shown in figure 10 (Ottlé et al. 2011). In the case of the MFO park shown in figure 11, where a steel structure supports climbing plants, a LCA calculation should be made specifically.

In most of the studies only the micro-scale benefits are taken into account. This is due to a lack of data regarding especially the macro-scale benefits and connected to the eco-systemic services. When it will be possible to consider (either economically and environmentally) all the unquantifiable benefits (also related to ecosystem services), the systems for the integration of vegetation in architecture will become more attractive. Also the aesthetical aspects play a role inside the systems evaluation, since a green envelope could increase the building (and neighbourhood) economical value.

\section{Summary}

The systems for the integration of vegetation in architecture (vertical green, green roofs and ground treatment in the vicinity of the building) and their environmental benefits are the subject of studies and researches starting from the Eighties (Köhler, 2008) but are not yet fully accepted as an energy saving method for the built environment, especially the most innovative vertical greening systems (living wall systems). The systems' design can take into account many environmental and economical aspects to avoid a larger use of green envelopes in the urban area.

A deeper study of the benefits related to the integration of vegetation in the building envelope could allow also a wider attention to this topic inside the building technical regulations.

Regulations usually take into account the need to control answer modalities related to requirements of the community but considering the availability of data with a carefully attention to avoid inequality in the related market. This implies that technology regulations come out after the time needed for a comparison with the sectors involved and after the evaluation of a validation system that clearly allows identifying the performances evaluation. Experimental researches allow realizing, refining, and validating calculation systems for innovative technologies certificating theirs effectiveness and thus encouraging designers (architects, engineers, companies, etc.) to the use of new technologies.

An other key element for a wider diffusion of greened envelopes regards the citizens' perception of vegetation elements, which is connected to the success of the integration (maintenance problems) and to the increase value of the building. Researches, as the one conducted by Perussia (2010), show that the presence of vegetation has a role on the well-being and residential satisfaction of the city's inhabitants. However these studies regard the perception of vegetation and not specifically vertical greening systems or green roofs.

The Social perception is based on the sum of two processes arising from what is perceived through our senses and from interpersonal relational exchanges which take a great part from culture, values, rituals, stereotypes and prejudices, modified and changed through the activity of communication. The introduction of a new element (like a green façade or roof) in our usual habitat stimulate our sensorial and social perceptions, setting in motion memories, habits, prejudices, stereotypes, hopes, desires, which influence our opinions and actions. To know all this is important because a negative perception can produce waste or degradation with social and economic consequences (Gazzola et al., 2004).

A study conducted by Schlösser (2003), showingthe difference between the main arguments pros and cons of facade greenery, noticed thanks to interviews with citizens living in greened houses and living in non-greened houses. The interviewees living in non-greened house show more enthusiasm for greenery in general (more nature in cities, visual enhanced cityscape and better feelings of citizens) and the ones living in greened house recognize the role of vegetation for a better air quality, thermal insulation. For the contra arguments citizens living in greened house give more importance, unlike citizens living in a non-greened house, to frequently cutting and less to damages at the facades and more insects.

The use of vegetation in the field of architecture design doesn't regard only the validation of its efficiency or the users approval, as previously described. It has also to be taken into account the designers' difficulty to see greening systems as building materials. It's true that green envelops are characterized by a sustainable aesthetic outcome (even if the real sustainability, as shown, has to be demonstrated), which is nowadays relevant for the market; but these systems are very different from the conventional construction materials able to look and perform strong and immutable, which is what many architects still look for. Greening systems are dynamic elements; those systems change aspect and performances in the course of time and are "mortal" as who designed them. This is for sure a different vision of what we usually call Architecture. 


\section{References}

Alexandri, E., Jones, P. (2008).Temperature decrease in a urban canyon due to green walls and green roofs in diverse climates. Building and Environment, 43, 480-493. http://dx.doi.org/10.1016/j.buildenv.2006.10.055

Ambasz, E. (2009). The Green over the Grey - landscape-cum-building design. Green roofs - Bringing nature back to town, Tagungsband International Green Roof Congress, 15-17.

Bartfelder, F., \& Köhler, M. (1987). Experimentelleuntersuchungenzur function von fassadenbegrünungen, Dissertation TU Berlin 612S.

Bartfelder, F., \& Köhler, M. (1987). Experimentelleuntersuchungenzur function von fassadenbegrünungen, Abbildungen, tabellen und literaturverzeichnis, Berlin.

Bohemen, van, H., (2005). Ecological engineering, bridging between ecology and civil engineering, Aeneas technical publishers.

Carter T., \& Keeler A. (2008). Life-cycle cost-benefit analysis of extensive vegetated roof systems, Journal of Environmental Management, 87 (3), 350-363. http://dx.doi.org/10.1016/j.jenvman.2007.01.024

Cassinelli, G., \& Perini, K. (2010). Esteticadell'architetturasostenibile.Eurau '10. ISBN 978-88-8497-162-3

DunnettN., \& Kingsbury N. (2004). Planting Green Roofs and Living Walls, Timber Press, Oregon.

Eumorfopoulou, E. A., \& Kontoleon, K. J. (2009). Experimental approach to the contribution of plant covered walls to the thermal behaviour of building envelopes. Building and Environment, 44, 1024e38.

Fioretti, R., Palla, A., Lanza, L.G., \& Principi, P. (2010). Green roof energy and water related performance in the Mediterranean climate. Building and Environment, 45, 1890-1904.

Gazzola, A., Carrer, F., Longoni, L., Pittamiglio, F., Poggi, F., \& Rimondi, D. (2004). Paesaggisociali (Social Landscapes), Coedit, Genova.

IPCC, 2001a. Climate Change. (2001). Impacts, Adaptation, and Vulnerability.Contribution of Working Group II to the third assessment report of the Intergovernmental Panel on Climate Change IPCC(2006).Cambridge University Press, Cambridge. 84 M.J. Metzger et al.Agriculture, Ecosystems and Environment, 114, 69-85.

IPCC, 2001b. Climate Change. (2001). Mitigation.Contribution of Working Group III to the third assessment report of the Intergovernmental Panel on Climate Change (IPCC) Cambridge University Press, Cambridge.

IPCC, 2001c. Climate Change. (2001). The Scientific Basis. Contribution of Working Group I to the third assessment report of the Intergovernmental PanelonClimateChange (IPCC) CambridgeUniversityPress, Cambridge.

Köhler M. (1993). Fassaden- und Dachbergrunung.Ulmer Fachbuch Landschafts- und Grunplanung, Stuttgart.

Köhler, M. (2008). Green façades-a view back and some vision. Urban Ecosyst, 11, $423-436$. http://dx.doi.org/10.1007/s11252-008-0063-X

Kosareo, L., \& Ries R. (2007). Comparative environmental life cycle assessment of green roofs.Building and Environment, 42, 2606-2613. http://dx.doi.org/10.1016/j.buildenv.2006.06.019

Krusche, P., Krusche, M., Althaus, D., \& Gabriel, I. (1982). Ökologischesbauen. Herausgegebenvomumweltbundesamt, Bauverlag.

Kumar R., \& Kaushik S. C. (2005). Performance evaluation of green roof and shading for thermal protection of buildings.Building and Environment, 40, 1505-1511. http://dx.doi.org/10.1016/j.buildenv.2004.11.015

Lambertini, A. (2007). Vertical Gardens, Verba Volant Ltd, London.

Metzger M. J., Rounsevell M. D. A., Acosta-Michlik, L., Leemans, R., \& Schro“ter, D. (2006). The vulnerability of ecosystem services to land use change. Agriculture, Ecosystems and Environment, 114, 69-85. http://dx.doi.org/10.1016/j.agee.2005.11.025

Niachou, A., et al. (2001). Analysis of the green roof thermal properties and investigationof its energy performance.Energy and Buildings, 33 (7), 719-729. http://dx.doi.org/10.1016/S0378-7788(01)00062-7

Onishi, A., Cao, X., Ito, T., Shi, F., \& Imura, H. (2010). Evaluating the potential for urban heat-island mitigation by greening parking lots. Urban Forestry \& Urban Greening.

Ottelé, M., Perini, K., Fraaij, A. L. A, Haas, E. M., \& Raiteri, R. (2011). Comparative life cycle analysis for green facades and living wall systems.Energy and Buildings, 43, 3419-3429. 
http://dx.doi.org/10.1016/j.enbuild.2011.09.010

Ottelé, M,. Van Bohemen, H., \& Fraaij, A.L.A. (2010). Quantifyng the deposition of particulate matter on climber vegetation on living walls.Ecological Engineering, 36, $154-162$. http://dx.doi.org/10.1016/j.ecoleng.2009.02.007

Palla, A., Gnecco, I., \& Lanza, L. G. (2010). Hydrogeologic Restoration in the Urban Environment Using Green Roofs.Water, 2, 140-154. http://dx.doi.org/10.3390/w2020140

Palla, A., Gnecco, I., \& Lanza, L. G. (2009). Unsaturated 2D modelling of subsurface water flow in the coarse-grained porous matrix of a green roof. Journal of Hydrology, 379, 193-204. http://dx.doi.org/10.1016/j.jhydrol.2009.10.008

Perini, K. (2012). Vegetation, architecture and sustainability. Article accepted in EAAE/ARCC International Conference on Architectural Research, Milan 7-10 June 2012 - Politecnico di Milano.

Perini, K., Ottelé M., Fraaij, A. L. A., Haas, M., \& Raiteri, R. (2011). Vertical green systems and the effect on air flow and temperature on the building envelope. Building and Environment, 46, $2287-2294$. http://dx.doi.org/10.1016/j.buildenv.2011.05.009

Perini K., Ottelé M., Haas E. M., \& Raiteri R. (2011). Greening the building envelope, façade greening and living wall systems.Open Journak of Ecology, 1(1), 1-8. http://dx.doi.org/10.4236/oje.2011.11001

Perussa F. (1990). Immagini di natura. ED. Guerini Studio, Italy.

Powe, N.A., \&Willis, K.G. (2004).Mortality and morbidity benefits of air pollution (SO2 and PM10) adsorption attributable to woodland in Britain.Journal of Environmental Management, 70, 119-128. http://dx.doi.org/10.1016/j.jenvman.2003.11.003

Schlösser, S. (2003). Zurakzeptanz von fassadenbegrünungen. Meinungsbilderkölnerbürger einebevölkerungsumfrage. PhD, Univ. Köln, pp 184.

Scudo, G., \& Ochoa De La Torre, J.. M., (2003). Spaziverdiurbani, Se, Napoli, Italy.

Stemberg, T., Viles, H., Carthersides, A., \& Edwards, M. (2010). Dust particulate absorption by Ivy (Hedera Helix L.) on historic walls in urban environments. Science of the Total Environment, 409, $162-168$. http://dx.doi.org/10.1016/j.scitotenv.2010.09.022

Taha, H. (1997). Urban climates and heat islands: albedo, evapotraspiration, and antropogenic heat. Energy and Buildings, 25, 99-103. http://dx.doi.org/10.1016/S0378-7788(96)00999-1

Ulrich, R. S., \& Simons, R. (1986). Recovery from stress during exposure to every day outdoor environments. In Wineman, J., Barns, R., Zimring, C., The costs of not knowing, procidings of the seventieth annual conference of the environmental research association, Washington DC.

Wong N. H., et al. (2003). Life cycle cost analysis of rooftop gardens in Singapore. Building and Environment, 38,499 - 509. http://dx.doi.org/10.1016/S0360-1323(02)00131-2

Wong N. H., et al. (2009). Thermal evaluation of vertical greenery systems for building walls. Building and Environment.

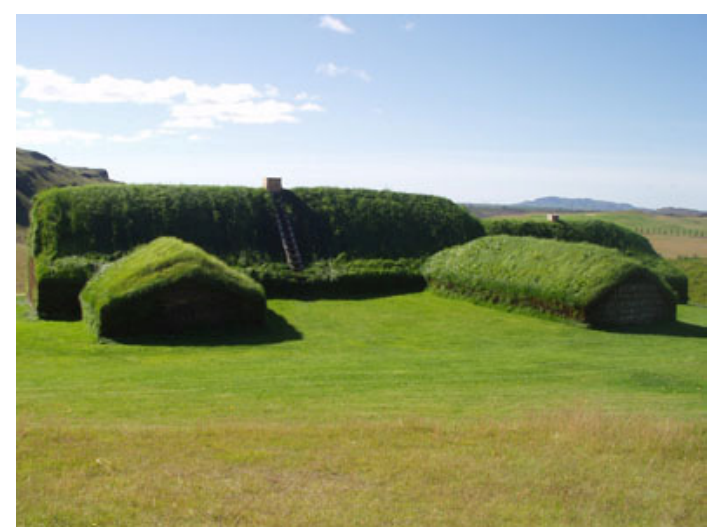

Figure 1. Traditional green roof in Iceland 


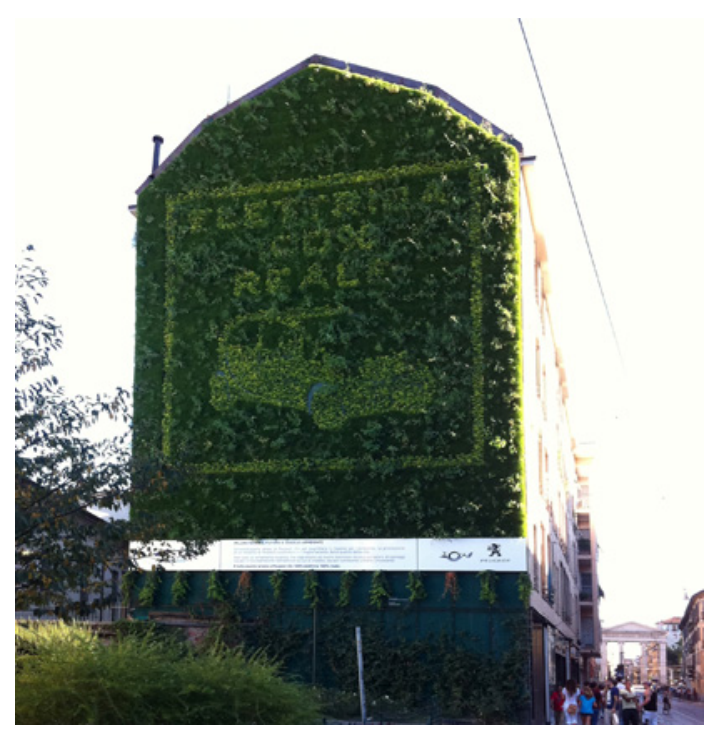

Figure 2. Green wall in Milan (Italy), Temprano, 2011

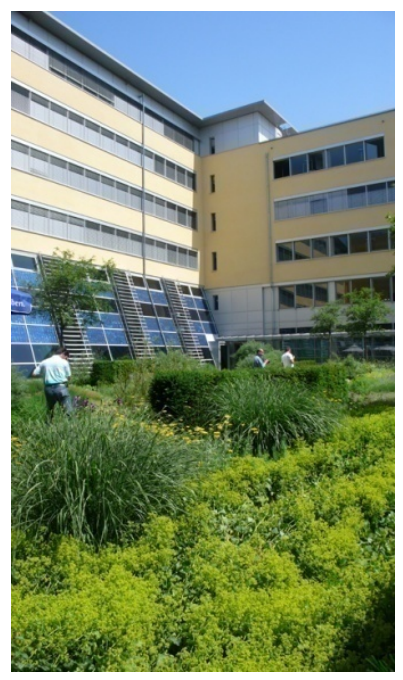

Figure 3. Intensive green roof, Friburg (Germany)

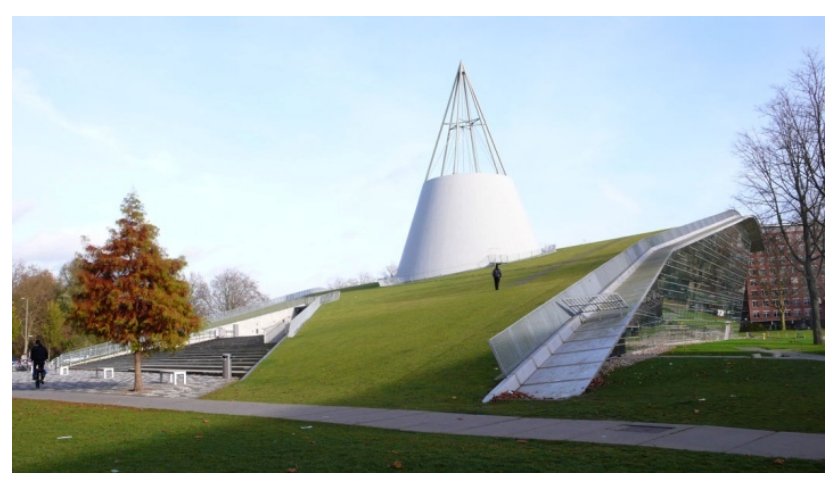

Figure 4. Library of Delft University of Technology (The Netherlands), Mecanoo, 1997 


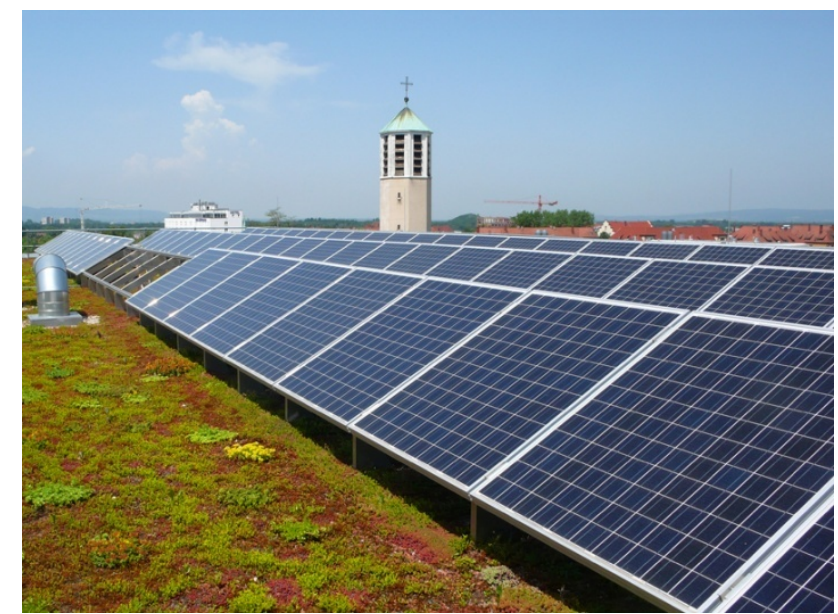

Figure 5. Extensive green roof, Friburg (Germany)

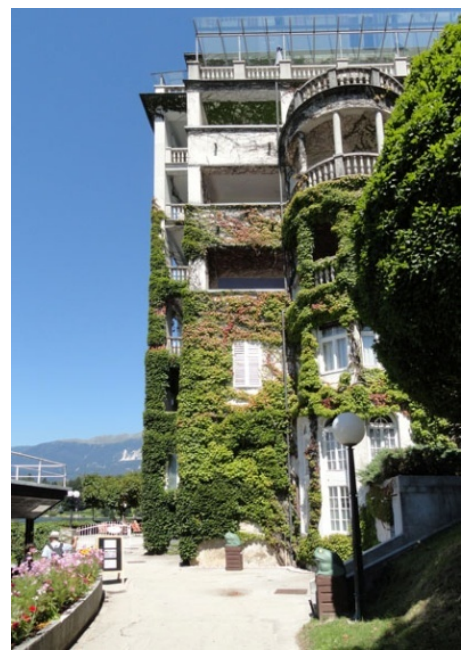

Figure 6. Direct greening system, Bled (Slovenia)

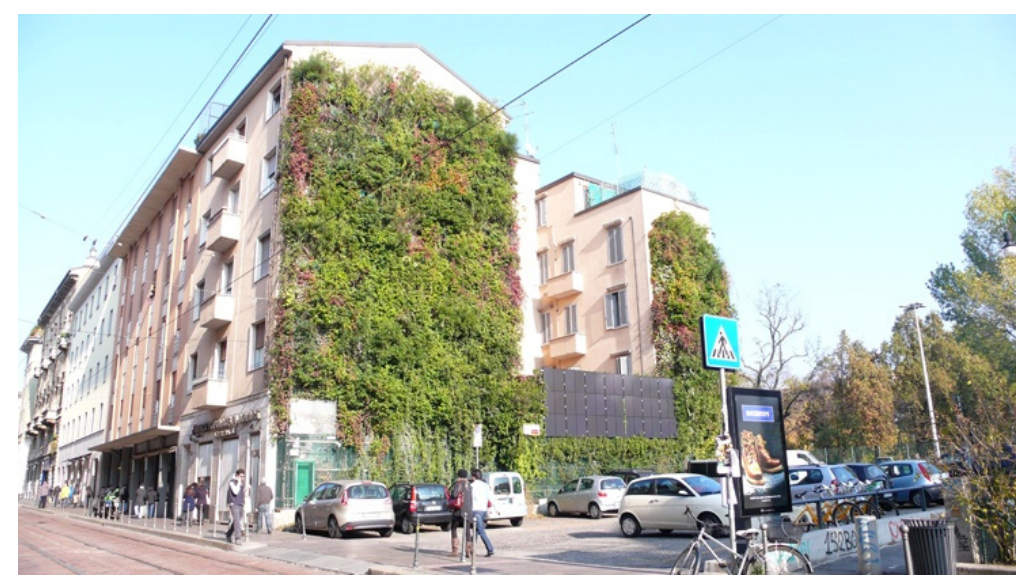

Figure 7. Indirect greening system (Laurusnobilis, Pittosporum, Nerium oleander, Genisteae, Jasminum) in Milan (Italy), Temprano, 2011 


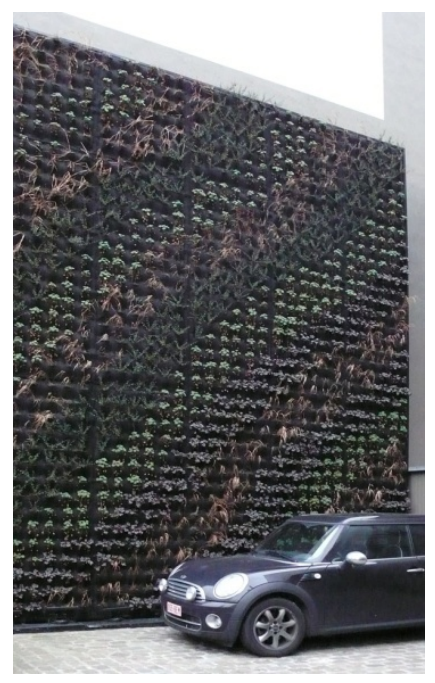

Figure 8. Living Wall system based on felt layers in a dealer in Antwerp (Belgium), 2011

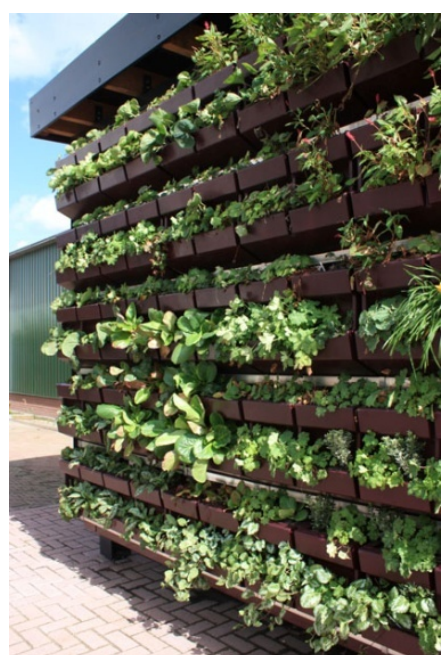

Figure 9. Living wall system based on planter boxes in Benthuizen (The Netherlands), Green Wave, 2010

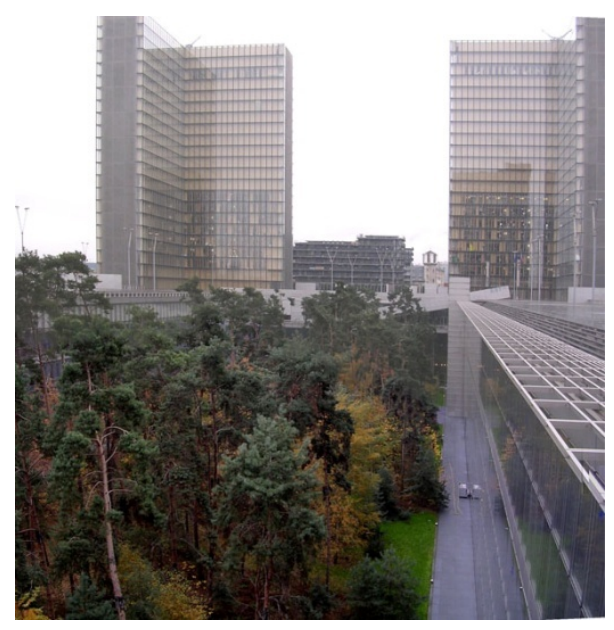

Figure 10. Court yard of the BibliothequeNationale de France in Paris, Dominique Perrault, 1997 


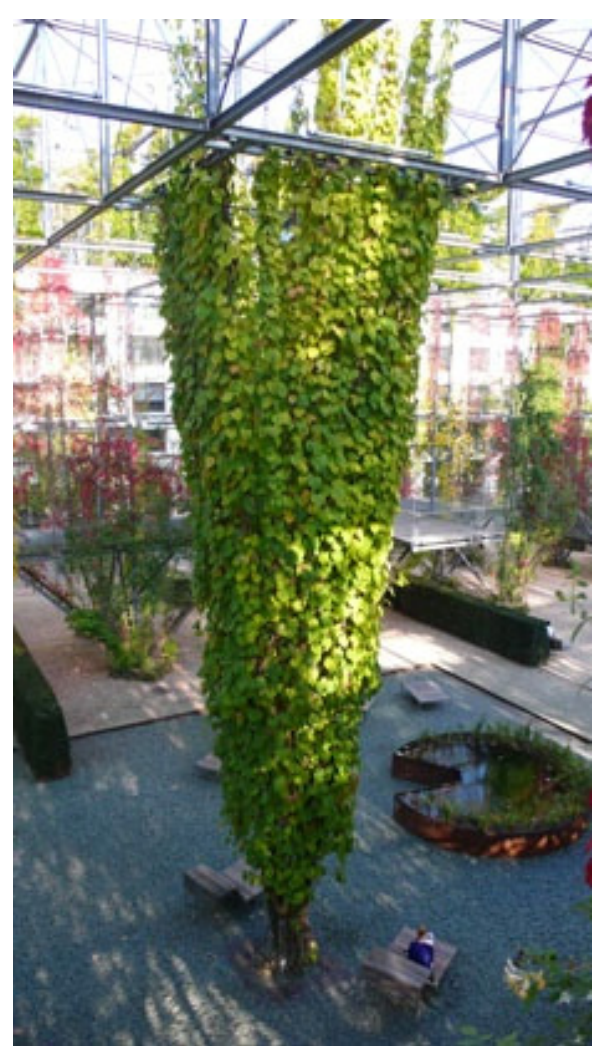

Figure 11. MFO-park in Zurich (Switzerland), Burckhardt + Partner AG RaderschallLandschaftsarchitekten, 2007 